\title{
Źródła wartości dla pokolenia X w usługach opartych na współdzieleniu
}

Michał Moneta*

\section{Wprowadzenie}

Serwicyzacja konsumpcji, czyli ,zastępowanie zaspokajania wybranych potrzeb we własnym zakresie przez korzystanie z rynkowej oferty usług" (Berbeka, Niemczyk 2017) wiąże się ze wzrostem roli usług w życiu współczesnego konsumenta. W krajach o gospodarce rynkowej proces ten nastąpił w latach 70. i 80. XX w., zaś w krajach postsocjalistycznych (w tym w Polsce) - w pierwszej i drugiej dekadzie XXI w. (Bywalec 2010). Jak zauważają Berbeka i Niemczyk, na wzrost znaczenia usług w życiu współczesnego konsumenta mają wpływ liczne czynniki: dążenie konsumentów do zwiększenia ilości czasu wolnego, zmiana sposobu tworzenia wartości dla konsumentów, wzrost znaczenia doświadczeń konsumenckich czy rozwój technologii informacyjnej (Berbeka, Niemczyk 2017).

Wzrost znaczenia usług w życiu konsumenta ${ }^{1}$ sprawił, że zaczęły się one różnicować. Nową kategorią usług są np. usługi oparte na współdzieleniu, funkcjonujące w ramach tzw. ekonomii współdzielenia (ang. sharing economy) - nowego nurtu ekonomiczno-społecznego, który pojawił się w wyniku nie tylko popularyzacji usług jako takich, lecz również wzrostu potrzeby racjonalnego gospodarowania zasobami czy ochrony środowiska naturalnego (Banaszek 2016). Ekonomia współdzielenia zakłada bowiem dzielenie się posiadanymi zasobami, np. mieszkaniem czy samochodem, oraz ich stałą wymianę, dzięki czemu zasoby są wykorzystywane w większym stopniu, co przekłada się na znaczne zredukowanie potrzeb konsumpcyjnych i rozsądne gospodarowanie przedmiotami. Nurt ten jest jednym z najistotniejszych obszarów współczesnych usług, a dzięki popularyzacji

* Michał Moneta - magister, doktorant, Szkoła Doktorska Nauk Społecznych Uniwersytetu Łódzkiego,michal.moneta@unilodz.eu.

${ }^{1}$ Konsument, w odróżnieniu od klienta czy nabywcy, to osoba funkcjonująca wyłącznie na rynku konsumenckim, na którym kupuje produkty oferowane przez firmy bądź wyłącznie z nich korzysta. 
aplikacji mobilnych i dostępowi do Internetu stał się również niezwykle szybko rozwijającą się gałęzią światowego biznesu (Ziobrowska 2016; Wagner I.K. 2019; Denny 2016).

Podstawą usług opartych na współdzieleniu są aplikacje mobilne i możliwość współpracy online, a to oznacza, że z tego rodzaju usług korzystają głównie pokolenia, dla których Internet jest naturalnym środowiskiem (Amaro, Andreu, Huang 2019). Za generację, która szczególnie chętnie używa usług opartych na współdzieleniu, uznaje się więc generację Y, czyli tzw. milenialsów (Cinjarevic, Kozo, Berberovic 2019; Williams 2018). W efekcie wiele publikacji poświęconych usługom opartym na współdzieleniu odnosi się właśnie do tego konkretnego pokolenia. Brakuje jednak analiz poświęconych innym generacjom klientów, a tymczasem szczególnie interesująca wydaje się generacja X, której aktywność w ramach usług opartych na współdzieleniu nie była dotychczas poddawana szeroko zakrojonym badaniom. W niektórych pracach pojawiały się krótkie analizy źródeł wartości - czyli jednego z głównych determinantów decyzji zakupowych (Sanchez-Fernandez, Iniesta-Bonillo 2006) - pokolenia X, jednak były one jedynie częścią większej całości i punktem odniesienia dla innej grupy odbiorców (Wagner I.K. 2019; Brkljac, Sudarevic 2018). Dotychczasowe publikacje z tego zakresu nie poruszały również kwestii wartości dla pokolenia X w kontekście konkretnego modelu teoretycznego i nie definiowały dominującej kategorii wartości, co tworzy istotną lukę badawczą w literaturze przedmiotu.

Generacja X to osoby urodzone w latach 1965-1985, z których część dorastała w okresie kryzysu gospodarczego lat 70. XX w. (Strauss, Howe 1997). Generacja ta weszła na rynek pracy w okresie problemów ekonomicznych na początku lat 90. XX w., a także doświadczyła pęknięcia bańki technologicznej na rynku akcji na przełomie XX i XXI w. Czynniki te znacząco wpłynęły na generację X, w szczególności na zachowawczość i niechęć do ryzyka, które charakteryzują jej wybory zakupowe (Tisdale 2016). Pokolenie X to także pierwsza generacja, która miała styczność z technologią cyfrową przez większą część życia. Warto również zauważyć, że - w przeciwieństwie np. do pokolenia $\mathrm{Y}$ - osoby urodzone w latach 1965-1985 w mniejszym stopniu chcą być częścią większej grupy i korzystać ze sprawdzonych pomysłów. Ich celem jest doświadczanie rzeczywistości „,na własnej skórze" i podejmowanie aktywności, które można realizować indywidualnie, bez wsparcia osób z zewnątrz (Mellan, Christie 2017). To także pokolenie, które w większym stopniu niż poprzednie zwraca uwagę na kwestie społeczne, a także na wpływ swoich działań na kondycję środowiska naturalnego (Denny 2016).

Powyższe rozważania pokazują, jak wiele czynników wpływa na decyzje konsumenckie pokolenia $X$, a określenie dominującej wartości w usługach opartych na współdzieleniu jest niemożliwe bez zbadania osób należących do tego pokolenia. Dwuetapowe badania przeprowadzone na potrzeby artykułu miały zatem na celu wskazanie kluczowego źródła wartości usług opartych na współdzieleniu 
dla generacji X. Pierwszym etapem było badanie jakościowe, które umożliwiło postawienie hipotez weryfikowanych w drugim etapie - ilościowym. Wyniki pozwoliły określić, która kategoria wartości postrzeganej przez konsumenta jest dominująca oraz które konkretne źródło tej wartości ma największe znaczenie dla pokolenia X w kontekście usług opartych na współdzieleniu.

\section{Teoretyczne ramy analizy}

Usługi oparte na współdzieleniu są definiowane jako część tzw. ekonomii społecznej, czyli „ekonomii opartej na wartościach partycypacji, solidarności oraz samorządności” (Banaszek 2016). Według Banaszka tego rodzaju rozwiązania wpisują się w nurt ekonomii społecznej, ponieważ opierają się na współdzieleniu zasobów ludzkich i materialnych (2016). Definicję tę rozwija Sundarajan, wskazując na ideę wirtualnej współpracy między jednostkami i podkreślając zarówno biznesowy, jak i czysto ideowy charakter współdzielenia (2016).

Jak już wspomniano, publikacje na temat korzystania z usług opartych na współdzieleniu koncentrują się głównie na pokoleniu Y, czyli na osobach urodzonych między 1985 a 2000 r. Problematykę tę podjęli m.in. Amaro, Andreu i Huang, wskazując na źródła wartości w korzystaniu przez milenialsów z Airbnb (2019), jak również Cinjarevic, Kozo i Berberovic, którzy analizowali kwestię zaufania i woli współpracy w kontekście chęci skorzystania z usług opartych na współdzieleniu (2019). Perspektywom rynku usług opartych na współdzieleniu w kontekście korzystania z nich przez pokolenie Y poświęcone zostały także projekt badawczy i raport „Millennials and the Sharing Economy: European Perspectives" (Ranzini $i$ in. 2017).

Usługi oparte na współdzieleniu analizowano również na zasadzie porównania różnych grup wiekowych użytkowników - opracowanie Chang i Wang koncentrowało się na ryzyku związanym z usługami opartymi na współdzieleniu. Autorzy uwzględnili w swojej publikacji generację X, definiując ją jako wyjątkowo czułą na oceny oferentów usług opartych na współdzieleniu (Chang, Wang 2018). Do podobnych wniosków doszły Wagner, Strulak-Wójcikiewicz i Landowska (2019), badając poziom zaufania do usług opartych na współdzieleniu przez różne pokolenia. Opracowania te koncentrowały się jednak na kosztach korzystania z Airbnb czy Ubera, nie definiując źródeł korzyści dla konsumentów, a tymczasem tytułowa wartość dla konsumenta odnosi się zarówno do kosztów korzystania z usługi, jak i płynących z niej korzyści (Sanchez-Fernandez, Iniesta-Bonillo 2007).

Analiza wartości usług opartych na współdzieleniu dla generacji X była także elementem prac opisujących ten problem z kilku innych perspektyw - m.in. częstotliwości korzystania, doświadczenia użytkowników, współpracy między 
użytkownikami czy zaufania do technologii. Jednym z najbardziej wartościowych opracowań jest artykuł Wagner koncentrujący się na motywacji do korzystania z wymienionych usług m.in. przez pokolenie X (Wagner I.K. 2019), jednak wniosek, że pokolenie X korzysta z usług opartych na współdzieleniu głównie z powodu wygody tych usług, wskazuje na potrzebę dalszych badań. Wagner nie określiła bowiem dominującej kategorii wartości ani nie oparła rozważań na konkretnym modelu teoretycznym. Jej opracowanie było analizą porównawczą, w której generacja $\mathrm{X}$ stanowiła jedynie punkt odniesienia dla pokolenia $\mathrm{Y}$ i baby boomers. Podobne podejście mieli także Denny (2016) oraz Brkljac i Sudarevic (2018), którzy w swoich pracach skupili się wyłącznie na wrażliwości generacji X na kwestie finansowe i nie podjęli innych obszarów analizy. W literaturze brakuje zatem kompleksowych opracowań na temat pokolenia X oraz nabywania i korzystania przez jego reprezentantów z usług opartych na współdzieleniu.

W kontekście tematyki artykułu za kluczowe należy uznać także pojęcie wartości, które w opinii m.in. Shetha, Newmana oraz Gross determinuje wybory konsumenckie (1991). Zdaniem autorów to właśnie wartość, jaką w danym produkcie lub usłudze widzi odbiorca, stoi za decyzją odnośnie do zakupu, odłożenia go na później czy też decyzją o całkowitej rezygnacji z kupna.

Na wstępie należy zauważyć, że wciąż nie ma jednoznacznej definicji wartości dla konsumenta, co sprawia, że bywa ona rozumiana i przedstawiana w różny sposób (Sanchez-Fernandez, Iniesta-Bonillo 2006). Jej najprostsze wyjaśnienie, zrównujące wartość z ceną, jaką należy zapłacić za produkt lub usługę, wydaje się najmniej trafne (Oliva 2000). Za zbyt wąskie uznawane jest również podejście określające wartość jako zwykłą wymianę pomiędzy korzyścią a wysiłkiem, który należy podjąć w celu jej uzyskania (Babin, Darden, Griffin 1994; Holbrook M.B. 1994). Istotę wartości znacznie lepiej oddaje podejście Holbrooka, który definiuje ją jako „wszystko to, co konsument otrzymuje w zamian za to, co daje” (1999).

Zdefiniowania wartości postrzeganej przez konsumenta podjęli się także Kotler oraz Lane Keller. Autorzy konkretyzują koszty, jakie ponosi klient: pieniężne, czasowe, psychologiczne oraz te związane z koniecznością poświęcenia energii (Kotler, Lane Keller 2014). Podejście to ma swoje źródła w publikacjach Monroe i Zeithaml, którzy zaznaczali, że konsument przy zakupie ponosi nie tylko koszty finansowe, ale także związane z czasem, wysiłkiem, wyborem produktu lub usługi, a także $\mathrm{z}$ bezpośrednią konsumpcją samego doświadczenia (Monroe 1990, Zeithaml 1988). Wartość postrzegana przez konsumenta jest zatem wieloaspektowym i znacznie szerszym podejściem niż popularyzowana głównie przez ekonomistów ze szkoły teorii racjonalnego wyboru definicja „wymiany pomiędzy użytecznością a ceną produktu" (Tellis, Gaeth 1990). Tego rodzaju szerokie i wieloaspektowe podejście jest fundamentem niniejszego artykułu.

Rozważania na temat definicji i istoty wartości postrzeganej przez konsumenta skłoniły badaczy do zaproponowania typologii wartości, które pozwoliły 
uporządkować i doprecyzować to pojęcie. Podstawowy dychotomiczny podział wartości postrzeganej przez konsumenta zaproponował Babin (1994), bazując na badaniach Hoolbroka oraz Hirschmana (1982). Typologia ta opierała się na wymiarze utylitarnym oraz hedonistycznym. Do bardziej rozbudowanych typologii wartości należy aksjologiczny model wartości Hartmana, który wyróżnił trzy wymiary wartości: zewnętrzny, wewnętrzny i systemowy (1967). Typologię Hartmana zaadaptował Mattsson (1991), nadając poszczególnym wymiarom wartości konkretną „ważność” w postrzeganiu przez konsumenta (Sanchez-Fernandez, Iniesta-Bonillo 2007).

Niniejszy artykuł opiera się na typologii Shetha, Gross i Newmana, która jest uznawana za najbardziej kompleksową typologię wartości (Sanchez-Fernandez, Iniesta-Bonillo 2007). Ich typologia, określana jako teoria wartości konsumpcyjnej, obejmuje pięć wymiarów, w których konsument może postrzegać wartość produktu lub usługi (Sheth, Newman, Gross 1991); należą do nich:

- wartość funkcjonalna - związana z postrzeganą użytecznością produktu, jego funkcjonalnością oraz atrybutami fizycznymi;

- wartość społeczna - uzyskiwana w wyniku powiązania dobra lub usługi z konkretną grupą społeczną, ma wpływ na wizerunek konsumenta;

- wartość emocjonalna - odnosząca się do uczuć towarzyszących zarówno procesowi zakupu, jak i konsumpcji oraz ewentualnym stanom końcowym;

- wartość kognitywna - skoncentrowana na ciekawości i niepewności związanej z produktem lub usługą;

- wartość sytuacyjna - związana z sytuacją zakupową, w której konkretne warunki otoczenia, czas czy sytuacja życiowa są głównym czynnikiem wpływającym na decyzję konsumenta.

Co ważne, jak zaznaczają autorzy konceptu, decyzje konsumenckie mogą być efektem oddziaływania zarówno jednego, jak i pięciu typów wartości (Sheth, Newman, Gross 1991).

$\mathrm{Z}$ analizy literatury wynika, że choć tematyka wartości dla konsumenta jest często i kompleksowo podejmowana przez badaczy z obszaru zarządzania, to jej odniesienie do usług opartych na współdzieleniu nie jest powszechną praktyką. Dotyczy to zwłaszcza analizy poszczególnych grup pokoleniowych. W tym kontekście szczególnie wartościowe będzie zbadanie generacji $\mathrm{X}$ - drugiego pod względem liczebności pokolenia użytkowników usług opartych na współdzieleniu (SurveyMonkey 2019). Uzupełnienie wiedzy z tego zakresu pozwoli lepiej zrozumieć motywy konsumenckie tej grupy wiekowej i może stać się fundamentem strategii oraz aktywności marketingowych kierowanych do bardzo znaczącej grupy potencjalnych klientów. 


\section{Metodyka badania}

W celu poznania dominujących źródeł wartości usług opartych na współdzieleniu dla pokolenia $\mathrm{X}$ przeprowadzono dwa etapy badań opartych na różnych metodach badawczych. Etap pierwszy, badania jakościowe, miał na celu uzyskanie ogólnej wiedzy na temat funkcjonalnych, społecznych, emocjonalnych, sytuacyjnych i kognitywnych aspektów korzystania z usług opartych na współdzieleniu.

Badania jakościowe bazowały na metodyce teorii ugruntowanej. Zgodnie z jej założeniami przed rozpoczęciem badań nie postawiono hipotez badawczych, a sam sposób interpretacji był indukcyjny, co umożliwiło lepsze zrozumienie analizowanej rzeczywistości (Kacprzak 2017). Celem badania jakościowego było zatem także postawienie hipotez badawczych. Scenariusz wywiadu w ramach badania jakościowego oparto na typologii wartości Shetha, Newmana i Gross.

Badanie jakościowe przeprowadzono w styczniu 2019 r. metodą pogłębionego wywiadu indywidualnego (IDI) na próbie 13 respondentów. Metoda ta miała na celu uzyskanie szerokiego, holistycznego opisu badanego zjawiska, uwzględniającego również „interpretację znaczenia opisywanych zjawisk” (Kvale 2012). Wywiad był częściowo strukturyzowany, a do jego przeprowadzenia posłużył przygotowany wcześniej scenariusz. Z palety możliwych do wykorzystania metod doboru nielosowego wybrano metodę doboru jednostek typowych, akceptowalną w przypadku badań wstępnych i rozpoznawczych (Marak 2016).

Wyniki badania jakościowego wskazały, że źródła wartości usług opartych na współdzieleniu dostrzegane przez pokolenie X należą do każdej kategorii wartości według typologii Shetha, Newmana i Gross (1991), a najczęściej pojawiającą się podczas wywiadu z respondentami kategorią była wartość funkcjonalna. Odpowiadający bardzo chętnie podkreślali przede wszystkim niższy koszt usług opartych na współdzieleniu względem tradycyjnych rozwiązań, zwracali uwagę również na oszczędność czasową. Pozwala to sformułować główną hipotezę związaną z podstawowym celem pracy:

H1: „Dla pokolenia $X$ wartość funkcjonalna ma większy wpływ na wartość usług opartych na współdzieleniu niż inne kategorie wartości według typologii Shetha, Gross i Newmana".

Wspomniana kilkakrotnie w badaniach kwestia kosztów wymaga jednak sprawdzenia pod kątem dochodów respondentów. Istnieje bowiem prawdopodobieństwo, że osoby z mniej zasobnym portfelem mogą widzieć w niskich kosztach usług większą wartość niż osoby zarabiające więcej. Aby to zweryfikować, postawiono hipotezę:

H2: „Niższe od przeciętnych zarobki wpływają na wyższą ocenę istotności wartości funkcjonalnej usług opartych na współdzieleniu”. 
Z badań wynika, że istotną kategorią wartości była również wartość społeczna. Do źródeł wartości należących do tej kategorii zalicza się przede wszystkim kreowanie określonego wizerunku dzięki korzystaniu z usług opartych na współdzieleniu - wizerunku osoby zaradnej, otwartej i ekonomicznej.

Wartość emocjonalna przejawiała się w odpowiedziach respondentów głównie jako zadowolenie z korzystania z usług. Część odpowiadających wskazywała na satysfakcję ze znalezienia rozwiązania, które usprawnia te dostępne obecnie na rynku, a część czerpała radość z wyszukania najlepszej opcji w danej aplikacji, np. Airbnb.

Ciekawość samego doświadczenia była głównym źródłem wartości kognitywnej. Respondenci przytaczali sytuacje, w których samo oczekiwanie na realizację usługi wiązało się z pewnego rodzaju ekscytacją i pozytywną niepewnością. Istotność wartości kognitywnej wymaga analizy pod kątem doświadczenia z usługami opartymi na współdzieleniu. Badanie jakościowe wskazało bowiem, że kwestie związane z wartością kognitywną częściej podnosiły osoby korzystające z usług opartych na współdzieleniu rzadko lub te, które skorzystały z nich po raz pierwszy. Ponadto, jak zaznacza Kahneman, drugie podobne doświadczenie, choćby niezwykle nietypowe, nie jest już tak zaskakujące jak pierwsze (2012). Zweryfikujmy zatem hipotezę:

H3: „Im większe doświadczenie w korzystaniu z usług opartych na współdzieleniu, tym niższa istotność wartości kognitywnej”.

W przypadku ostatniej kategorii w typologii wartości Shetha, Newmana i Gross, wartości sytuacyjnej, trudno wyróżnić jej jedno, dominujące źródło. Odpowiedzi respondentów wskazywały na bardzo wiele sytuacji, w których usługa oparta na współdzieleniu stanowiła idealne rozwiązanie. W wywiadach mówili oni zarówno o korzystaniu z niej w konkretnych okresach roku, jak również w określonych sytuacjach (prywatnej lub służbowej) czy miejscach.

Badanie jakościowe było punktem wyjścia do kolejnej części badań, ilościowej, której głównym celem była weryfikacja hipotezy H1, a co za tym idzie - wskazanie dominującej kategorii wartości. Badanie miało na celu również zweryfikowanie hipotez H2 i H3. Przeprowadzono je przy użyciu metody CAWI ze względu na łatwość jej zastosowania i dotarcia do odbiorców - zdecydowana większość pokolenia $X$ jest aktywnymi użytkownikami sieci (IAB Polska, 2018). Próbę badawczą wyłoniono w wyniku doboru celowego, który umożliwił dotarcie do konkretnych osób spełniających kryteria badania.

Odpowiedzi respondentów uzyskane w badaniu jakościowym, a przede wszystkim ich późniejsza analiza i kodowanie pozwoliły przygotować listę najczęściej wskazywanych źródeł wartości. Źródła, pogrupowane zgodnie z typologią wartości Shetha, Gross i Newmana, stworzyły pięć kategorii wartości: funkcjonalną, społeczną, emocjonalną, kognitywną oraz sytuacyjną. Aby zapewnić równość między poszczególnymi kategoriami, do każdej z nich zostały wybrane po cztery źródła wartości. Respondenci mieli do dyspozycji siedmiostopniową 
skalę (zastosowany został dyferencjał semantyczny), której najniższa wartość (1) oznaczała bardzo niski wpływ danego źródła wartości, zaś wartość najwyższa (7) - na bardzo duży wpływ czynnika.

Badanie ilościowe trwało od stycznia do marca 2019 r. Wzięło w nim udział 104 respondentów, jednak $31 \mathrm{z}$ nich zostało odrzuconych, ponieważ nie spełnili oni kryterium wieku oraz konieczności posiadania doświadczenia w korzystaniu z usług opartych na współdzieleniu, co dało 73 ważne wyniki.

\section{Źródła wartości - istotność według użytkowników $\mathrm{Z}$ pokolenia $\mathrm{X}$}

Próbę badawczą podzielono zgodnie z następującymi kryteriami: wiek, miejsce zamieszkania, stan cywilny, dochód w przeliczeniu na członka rodziny, poziom wykształcenia, doświadczenie w korzystaniu z usług opartych na współdzieleniu, rodzaj usług, z których korzystał respondent, oraz czas ostatniego korzystania $z$ tego rodzaju rozwiązań. Badanie bazowało na porównaniu istotności każdej z pięciu kategorii typologii Shetha, Newmana i Gross, w których zawarte były poszczególne źródła wartości. Średnie dla każdej kategorii są podstawą oceny istotności danego typu wartości w odbiorze usług opartych na współdzieleniu.

\section{Weryfikacja hipotezy $\mathrm{H} 1$}

Głównym celem badania ilościowego była weryfikacja hipotezy H1, zgodnie z którą „dla pokolenia X wartość funkcjonalna ma większy wpływ na wartość usług opartych na współdzieleniu niż inne kategorie wartości według typologii Shetha, Gross i Newmana”. W tym celu porównano ze sobą średnią istotność poszczególnych kategorii typologii. Wyniki zaprezentowano w Tabeli 1.

Tabela 1. Porównanie średnich dla kategorii

\begin{tabular}{|l|c|c|c|c|c|}
\cline { 2 - 6 } \multicolumn{1}{c|}{} & $\begin{array}{c}\text { Śr. wartości } \\
\text { funkcjonalnej }\end{array}$ & $\begin{array}{c}\text { Śr. wartości } \\
\text { spolecznej }\end{array}$ & $\begin{array}{c}\text { Śr. wartości } \\
\text { emocjonalnej }\end{array}$ & $\begin{array}{c}\text { Śr. wartości } \\
\text { kognitywnej }\end{array}$ & $\begin{array}{c}\text { Śr. wartości } \\
\text { sytuacyjnej }\end{array}$ \\
\hline Średnia & 5,24 & 3,03 & 3,95 & 3,94 & 4,54 \\
\hline O. standardowe & 1,27 & 1,35 & 1,31 & 1,16 & 1,18 \\
\hline
\end{tabular}

Źródło: opracowanie własne.

Zdecydowanie najwyższą średnią oceną istotności wpływu poszczególnych czynników na wartość usługi charakteryzowała się kategoria wartości funkcjonalnej, co potwierdza hipotezę główną H1. Wysoka średnia ocena źródeł wartości należących do kategorii wartości funkcjonalnej jest zgodna z wnioskami płynącymi z poprzedniego etapu badania. 
Również z porównania poszczególnych źródeł wynika, że to niski koszt usług opartych na współdzieleniu jest najważniejszym źródłem wartości dla pokolenia X. Oceny dotyczące kosztów były też najbardziej jednorodne - w ich przypadku odchylenie standardowe jest najniższe. Nie ma zatem podstaw do odrzucenia hipotezy H1, zgodnie z którą , dla pokolenia X wartość funkcjonalna ma większy wpływ na wartość usług opartych na współdzieleniu niż inne kategorie wartości według typologii Shetha, Gross i Newmana".

\section{Weryfikacja hipotezy $\mathrm{H} 2$}

W badaniach zweryfikowano hipotezę $\mathrm{H} 2$ : , niskie zarobki mają wpływ na wyższą ocenę istotności wartości funkcjonalnej usług opartych na współdzieleniu". Wyniki tej analizy przedstawiono w Tabeli 2.

Tabela 2. Analiza korelacji w ramach hipotezy $\mathrm{H} 2$

\begin{tabular}{|c|l|l|c|c|}
\cline { 3 - 4 } \multicolumn{2}{l|}{} & Niższy koszt & Miesięczny dochód \\
\hline \multirow{2}{*}{ Rho Spearmana } & \multirow{2}{*}{ Niższy koszt } & Współczynnik korelacji & 1 & $-0,115$ \\
\cline { 3 - 5 } & & Istotność (dwustronna) & & 0,334 \\
\hline
\end{tabular}

Źródło: opracowanie własne.

Korelacja na poziomie $-0,115$ wskazuje na słaby związek między wzrostem wysokości dochodów a oceną istotności niskich kosztów usług opartych na współdzieleniu. Korelacja ta przyjmuje wartość ujemną, co oznacza, że wzrost dochodów powoduje obniżenie istotności czynnika. Co więcej, istotność dwustronna na poziomie 0,334 nie pozwala przyjąć hipotezy $\mathrm{H} 2$.

\section{Weryfikacja hipotezy H3}

Weryfikacji wymagała także hipoteza H3, zgodnie z którą ,im większe doświadczenie w korzystaniu z usług opartych na współdzieleniu, tym niższa istotność wartości kognitywnej”.

Tabela 3. Średnia ocen wartości kognitywnej

\begin{tabular}{|c|c|c|}
\hline Średnia & $\mathbf{N}$ & O. standardowe \\
\hline 3,94 & 73 & 1,16 \\
\hline
\end{tabular}

Źródło: opracowanie własne.

Średnia ocen źródeł wartości kognitywnych jest podobna do średniej źródeł wartości emocjonalnej. Wynik ten potwierdza wnioski płynące z badania 
jakościowego - kwestie poznawcze usług opartych na współdzieleniu nie są dominującą kategorią wartości tego rodzaju rozwiązań. Porównanie znajduje się w Tabeli 4.

Tabela 4. Porównanie źródeł wartości kognitywnej

\begin{tabular}{|c|c|c|c|c|}
\cline { 2 - 5 } \multicolumn{1}{c|}{} & $\begin{array}{c}\text { Ciekawość } \\
\text { samej usługi }\end{array}$ & $\begin{array}{c}\text { Nietypowość usług } \\
\text { opartych } \\
\text { na wspóldzieleniu }\end{array}$ & $\begin{array}{c}\text { Chęć sprawdzenia } \\
\text { usług opartych } \\
\text { na współdzieleniu }\end{array}$ & $\begin{array}{c}\text { Chęć znalezienia } \\
\text { najbardziej } \\
\text { optymalnej opcji } \\
\text { na rynku }\end{array}$ \\
\hline Średnia & 3,82 & 3,03 & 3,49 & 5,42 \\
\hline
\end{tabular}

Źródło: opracowanie własne.

Aby zweryfikować hipotezę H3, wartość kognitywną przeanalizowano również pod kątem doświadczenia respondentów w korzystaniu z usług opartych na współdzieleniu. Wyniki analizy znajdują się w Tabeli 5.

Tabela 5. Analiza korelacji w ramach hipotezy $\mathrm{H} 3$

\begin{tabular}{|l|l|l|c|c|}
\cline { 3 - 4 } \multicolumn{2}{c|}{} & $\begin{array}{c}\text { Średnia } \\
\text { wartości } \\
\text { kognitywnej }\end{array}$ & $\begin{array}{c}\text { Doświadczenie w korzystaniu } \\
\text { z uslug opartych } \\
\text { na współdzieleniu }\end{array}$ \\
\hline \multirow{2}{*}{ Rho Spearmana } & $\begin{array}{l}\text { Średnia } \\
\text { wartości } \\
\text { kognitywnej }\end{array}$ & $\begin{array}{l}\text { Współczynnik } \\
\text { korelacji }\end{array}$ & 1 & 0,009 \\
\cline { 3 - 5 } & $\begin{array}{l}\text { Istotność } \\
\text { (dwustronna) }\end{array}$ & & 0,940 \\
\hline
\end{tabular}

Źródło: opracowanie własne.

Jak wynika z Tabeli 5, korelacja między poziomem doświadczenia konsumenta a oceną kategorii wartości kognitywnej nie osiąga wysokiej wartości ujemnej, tylko jest dodatnia. Korelacja ta jest ponadto niezwykle słaba, co przy istotności 0,94 nie pozwala przyjąc hipotezy H3, zgodnie z którą ,im większe doświadczenie w korzystaniu z usług opartych na współdzieleniu, tym niższa istotność wartości kognitywnej”.

\section{Podsumowanie}

Dwuetapowe badania wykazały, że należący do pokolenia X użytkownicy usług opartych na współdzieleniu widzą największą wartość w funkcjonalnych aspektach Airbnb czy Ubera, przedkładając je nad inne kategorie. Za najważniejsze źródła wartości funkcjonalnej uznają przede wszystkim niższe koszty usług opartych na współdzieleniu w porównaniu z kosztami komercyjnych rozwiązań. Badanie ilościowe nie dało zatem podstaw do odrzucenia hipotezy głównej H1, postawionej 
po badaniu jakościowym, oraz korespondowało z wnioskami płynącymi z analizy literatury dotyczącej zachowań konsumenckich pokolenia X. Denny, Gronbach czy Brkljac i Sudarevic wskazywali bowiem, że jest to generacja szczególnie wyczulona na aspekty finansowe, głównie z powodu dojrzewania w czasie kryzysów gospodarczych w USA oraz ciężkiej rzeczywistości PRL w Polsce. Usługi takie jak Uber czy Airbnb pozwalają osobom z generacji X zaoszczędzić środki, które musiałyby one wyłożyć na taksówki czy hotele. Co więcej, kwestie finansowe były głównym źródłem wartości usług opartych na współdzieleniu dla osób o zarówno najniższych, jak i najwyższych dochodach.

Wskazanie wartości funkcjonalnej jako dominującej kategorii oraz niskich kosztów jako dominującego źródła wartości pozwala wypełnić lukę badawczą, o której była mowa podczas analizy literatury dotyczącej problemu badawczego pracy. Dotychczasowe prace, np. artykuły Wagner czy Brkljaca i Sudarevica, nie precyzowały bowiem, jakiego rodzaju wartość usług opartych na współdzieleniu jest najistotniejsza przy podejmowaniu decyzji konsumenckich przez pokolenie X. Opracowanie Wagner, choć wyczerpujące i definiujące główne źródło wartości konsumenckiej tego typu usług, skupiało się niemal wyłącznie na wartościach społecznej, funkcjonalnej i sytuacyjnej, pomijając aspekty kognitywne i emocjonalne. Przeprowadzone na potrzeby niniejszego artykułu badania wzbogacają zatem wiedzę na temat motywów zakupowych użytkowników usług opartych na współdzieleniu oraz pogłębiają podejmowaną w innych pracach analizę pokolenia X jako konsumentów.

Niezbyt istotne okazały się czynniki związane z wartością społeczną, co rzuca nowe światło na postrzeganie wartości konsumenta należącego do pokolenia X. Literatura, w szczególności prace Denny i Eisner, wskazywała na większą rolę odpowiedzialności społecznej w podejmowaniu decyzji konsumenckich przez tę generację. Jak jednak wynika z badania ilościowego, kategoria ta ma najmniejszy wpływ na wartość usług opartych na współdzieleniu i nie przynosi niemal żadnych korzyści użytkownikom należącym do pokolenia X.

Kategorie wartości emocjonalnej i kognitywnej, niepoddawane dotąd szerokiej analizie w literaturze, są istotne dla pokolenia X w podobnym stopniu i plasują się pomiędzy najbardziej istotnymi czynnikami, funkcjonalnymi, i najmniej ważnymi, społecznymi. Jednocześnie w badaniu odrzucono hipotezę zakładającą, że ocena istotności źródeł wartości kognitywnej zależy od poziomu doświadczenia użytkownika korzystającego z usług opartych na współdzieleniu.

Za zaskakujące, zwłaszcza w kontekście analizy literatury oraz jakościowej części badań, należy uznać wysokie wyniki istotności wartości sytuacyjnej. Konsumenci należący do pokolenia X bardzo mocno kojarzą usługi oparte na współdzieleniu z konkretnymi sytuacjami, miejscami i porami roku. Najistotniejszym źródłem wartości sytuacyjnej była możliwość korzystania z tego rodzaju rozwiązań w nieznanych lokalizacjach. Okazało się, że Uber czy Airbnb są niezwykle przydatne wtedy, kiedy użytkownik musi przemieszczać się po obcym mieście 
lub zarezerwować nocleg w odległej miejscowości. Konsumenci z pokolenia X bardzo mocno kojarzą usługi oparte na współdzieleniu właśnie $\mathrm{z}$ tego rodzaju sytuacjami, co pozwala wnioskować, że w takich przypadkach to właśnie Uber i Airbnb, a nie taksówki i hotele, będą ich pierwszym wyborem. To istotny wniosek nie tylko dla obszaru naukowego, ale przede wszystkim dla praktyki biznesowej i marketingowej związanej z rynkiem współczesnych usług.

Celowy dobór próby wskazuje na potrzebę pogłębienia analiz na większej próbie dobranej w sposób losowy. Pozwoli to wzbogacić literaturę na temat usług opartych na współdzieleniu, wartości konsumenckiej i pokolenia X o kolejne reprezentatywne wnioski. Ponieważ tego rodzaju usługi są wciąż dość nowe, a w dodatku ciągle się rozwijają, tematyka ta powinna być w dalszym ciągu eksploatowana w ramach badań marketingowych, socjologicznych i psychologicznych. Umożliwi to lepsze zrozumienie decyzji podejmowanych w przypadku tego typu usług.

W kolejnych badaniach związanych ze źródłami usług opartych na współdzieleniu warto przede wszystkim posłużyć się inną typologią wartości niż ta, która została użyta w niniejszym opracowaniu. Pozwoli to skonfrontować wyniki dwóch niezależnych analiz oraz wykluczyć ich ewentualne zniekształcenia wywołane przyjętą typologią. Niezwykle wartościowe byłoby również porównanie wartości usług opartych na współdzieleniu - bazujące na typologii Shetha, Newmana i Gross - dla generacji X z oceną innej grupy pokoleniowej. Tego rodzaju praca pokazałaby różnice między pokoleniami, jeśli chodzi o ich stosunek do innowacyjnych, współdzielonych rozwiązań, i byłaby wartościowym materiałem dla osób zajmujących się komunikacją marketingową z różnymi grupami odbiorców.

Warto również rozważyć zbadanie tych reprezentantów pokolenia $\mathrm{X}$, którzy występują w roli nie konsumentów, lecz oferentów usług opartych na współdzieleniu. Sam etap badania jakościowego i eksploracja potencjalnych źródeł mogłyby dostarczyć zupełnie innych wniosków niż te, które zostały sformułowane na podstawie indywidualnych wywiadów pogłębionych $\mathrm{z}$ użytkownikami tych usług. Połączenie badania użytkowników z badaniem respondentów pozwoli uzyskać kompleksowy materiał na temat wartości usług opartych na współdzieleniu dla generacji $X$.

\section{Bibliografia}

Amaro S., Andreu L., Huang S. (2019), Millenials' intentions to book on Airbnb, „Current Issues in Tourism”, 22 (18), s. 2284-2298.

Babin B., Darden W., Griffin M. (1994), Work and/or Fun: Measuring Hedonic and Utilitarian Shopping, ,Journal of Consumer Research”, 20 (4), s. 644-656.

Banaszek M. (2016), Ekonomia współdzielenia jako alternatywny kierunek rozwoju miast, „Ekonomia społeczna”, 1, s. 51-59. 
Berbeka J., Niemczyk A. (2017), Znaczenie i rozwój ustug a zachowania wspótczesnego konsumenta [w:] M. Bartosik-Purgat, Zachowania konsumentów, Wydawnictwo Naukowe PWN, Warszawa.

Brkljac M., Sudarevic T.J. (2018), Sharing Economy and „Industry 4.0” as the Business Environment of Millennial Generation - a Marketing Perspective, Proceedings of the 29th International DAAAM Symposium 2018, DAMM, Zadar, s. 1092-1101.

Bywalec C. (2010), Konsumpcja a rozwój gospodarczy i społeczny, C.H. Beck, Warszawa.

Chang W.-L., Wang J.-Y. (2018), Mine is yours? Using sentiment analysis to explore the degree of risk in the sharing economy, „Electronic Commerce Research and Applications", 28, s. 141-158.

Cinjarevic M., Kozo A., Berberovic D. (2019), Sharing is Caring, and Millennials Do Care: Collaborative Consumption through the Eyes of Internet Generation, ,South East European Journal of Economics \& Business”, 14 (1), s. 49-60.

Denny M. (2016), The Business Side: 21st Century Marketing, Part II. Point of Beginning, Pobonline, http://www.pobonline.com/articles/100552-the-business-side-21st-century-marketing-part-ii (data dostępu: 18.09.2020).

Hartman R. (1967), The Structure of Value: Foundation of a Scientific Axiology, Southern Illinois Press, Carbondale.

Holbrook M.B. (1994), The Nature of Customer Value: An Axiology of Services in the Consumption Experience [w:] R. Rust, R.L. Oliver, Service Quality: New Directions in Theory and Practice, Sage Publications, Thousand Oaks, s. 21-71.

Holbrook M.B. (1999), Consumer Value. A Framework for Analysis and Research, Routledge, Londyn.

Holbrook M., Hirschman E. (1982), The Experiental Aspects of Consumption: Consumer Fantasies, Feelings and Fun, „Journal of Consumer Research”, 9 (2), s. 132-140.

IAB Polska (2018), Raport Strategiczny. Internet 2017/2018, Warszawa.

Kacprzak A. (2017), Marketing doświadczeń w Internecie, C.H. Beck, Warszawa.

Kahneman D. (2012), Pułapki myślenia. O myśleniu szybkim i wolnym, Media Rodzina, Poznań.

Kotler P., Lane Keller K. (2014), Marketing, Rebis, Poznań.

Kvale S. (2012), Prowadzenie wywiadów, Wydawnictwo Naukowe PWN, Warszawa. Marak J. (2016), Wykorzystanie metody ankietowej w badaniu zachowań podmiotów rynku [w:] Mazurek-Łopacińska K., Badania marketingowe, Wydawnictwo Naukowe PWN, Warszawa, s. 129-222.

Mattsson J. (1991), Better Business by the Abc of Values, Chartwell Learning \& Development Limited, Lund. 
Mellan O., Christie S. (2017), Thinking Gen X, ,Investment Advisor”, 37, s. 30-34. Monroe K. (1990), Pricing: Making Profitable Decisions, McGraw-Hill, New York.

Oliva R. (2000), Brainstorm your e-business, „Marketing Management”, 9, s. 55-57.

Ranzini G., Newlands G., Anselmi G. i in. (2017), Millennials and the Sharing Economy: European Perspectives, EU H2020 Research Project Ps2Share.

Sanchez-Fernandez R., Iniesta-Bonillo M.A. (2006), Consumer Perception of Value: Literature Review and a New Conceptual Framework, „Journal of Consumer Satisfaction, Dissatisfaction \& Complaining Behavior", 19, s. $40-58$.

Sanchez-Fernandez R., Iniesta-Bonillo M.A. (2007), The concept of perceived value: a systematic review of the research, „Marketing Theory”, 7 (4), s. $427-445$.

Sheth J.N., Newman B.I., Gross B.L. (1991), Why We Buy What We Buy: A Theory of Consumption Values, ,Journal of Business Research”, 22 (2), s. 159-170.

Strauss W., Howe N. (1997), The Fourth Turning: What the Cycles of History Tell Us about Americas Next Rendezvous With Destiny, Broadway Books, New York.

Sundararajan A. (2016), The Sharing Economy: The End of Employment and the Rise of Crowd-Based Capitalism, The MIT Press, Londyn.

SurveyMonkey (2019), Who likes the sharing economy? Most people, but especially millennials, SurveyMonkey, http://www.surveymonkey.com/mp/ who-likes-the-sharing-economy-most-people-but-especially-millennials (data dostępu: 19.09.2020).

Tellis G., Gaeth G. (1990), Best Value, Price-Seeking and Price Aversion: The Impact of Information and Learning on Consumer Choices, ,Journal of Marketing", 54 (2), s. 34-45.

Tisdale S. (2016), Generation X Turns 50!, Black Enterprise, 46, s. 22-23.

Wagner I.K. (2019), Sharing Economy Participation as a Function of Generational Cohort, Appalachian State University, Appalachian.

Wagner N., Strulak-Wójcikiewicz R., Landowska A. (2019), Trust in Sharing Economy Business Models from the Perspective of Customers in Szczecin, Poland, „Sustainability”, 11 (23), s. 1-26.

Williams R. (2018), Forrester: Millennials boost growth of sharing economy, http://www.mobilemarketer.com/news/forrester-millennials-boost-growth-of-sharing-economy/515851 (data dostępu: 18.09.2020).

Zeithaml V. (1988), Consumer Perceptions of Price, Quality and Value: A Mean-end Model and Synthesis of Evidence, „Journal of Marketing”, 52 (3), s. $2-22$.

Ziobrowska J. (2016), Sharing economy jako nowy trend konsumencki, Repozytorium Uniwersytetu Wrocławskiego. 


\section{Streszczenie}

Usługi oparte na współdzieleniu to jedna z najdynamiczniej rozwijających się gałęzi współczesnych usług. Rozwiązania takie jak Airbnb czy Uber często służą klientom nie tylko jako substytut tradycyjnych usług, lecz stają się ich pierwszym wyborem w przypadku podróży, przejazdów czy poszukiwania pracowników. W artykule przeanalizowano źródła wartości, jakie klienci należący do pokolenia $\mathrm{X}$ widzą w usługach opartych na współdzieleniu.

Celem badawczym artykułu było zatem określenie, które źródła wartości usług opartych na współdzieleniu wpływają na ich postrzeganie. Źródła skategoryzowano na podstawie typologii wartości Shetha, Newmana i Gross. Badania wykazały, że wśród źródeł wartości usług opartych na współdzieleniu dla pokolenia $\mathrm{X}$ dominują aspekty funkcjonalne. Badanie uwypukliło także istotność źródeł wartości sytuacyjnej z jednoczesnym pominięciem źródeł wartości społecznej i emocjonalnej.

Wyniki badań uzupełniają lukę badawczą w tematyce poświęconej źródłom wartości dla pokolenia $\mathrm{X}$ w usługach opartych na współdzieleniu, wskazując ich dominującą kategorię. $\mathrm{W}$ dalszych badaniach nad tym zagadnieniem wartościowe będzie poddanie generacji $\mathrm{X}$ analizie $\mathrm{z}$ wykorzystaniem innego modelu teoretycznego i porównanie jej z innymi pokoleniami.

Slowa kluczowe: usługi oparte na współdzieleniu, pokolenie X, wartość dla konsumenta

\section{Summary}

\section{Sources of customer value for Generation X in sharing-based services}

Shared services are one of the most dynamically developing branches of modern services. Airbnb and Uber often serve customers not only as a substitute for traditional services, but they become their first choice when it comes to travelling, rides or accommodation. The article indicates the sources of customer value in sharing-based services. The analysis was carried out on Generation X.

The research objective of the article was, therefore, to determine which sources of customer value of sharing-based services affect the perceived value. The categorisation was based on the typology of customer value created by Sheth, Newman and Gross. The results of the study indicated that functional aspects dominate among the sources of value of sharing-based services according to Generation X. The study also showed the importance of situational value and the omission of social and emotional value. 
The results of the research fill the research gap in the area of sources of value for Generation X in sharing-based services and indicate their dominant category. In further research, it will be valuable to analyse Generation $\mathrm{X}$ using a different theoretical model, as well as to compare Generation $\mathrm{X}$ with other age groups.

Keywords: sharing economy, Generation X, customer value

JEL: M21, M31 